\title{
Sartre's Notion of Human Reality: Why We are Radically Free within Our Social Roles
}

\author{
Miranda Kexin $\mathrm{Hu}^{1}$
}

\begin{abstract}
In a rigid social structure where individuals are assigned specific roles and are expected to behave according to such roles, do we still have the freedom of making meaning that transcends our social roles? Moreover, can we be different from and more than our social roles? This paper examines how Jean-Paul Sartre argues that we have the radical freedom to make meaning transcendent to our given roles despite living in a rigid social structure. According to Sartre, human consciousness has a nihilating structure that makes it nonidentical to the things in the world. Such structure prevents us from having a fixed identity that is entirely identical to our social role. The social pressure for individuals to only act as their social roles seems to undermine the very nihilating structure of consciousness since it simply reduces individuals to their social roles. However, such an attempt that treats people as things will always fail. Even though individuals may act according to their social roles due to social pressure, such pressure does not undermine the nihilating structure of consciousness. Thus, we still hold the radical power and freedom to take up our social roles and make different meanings out of them.
\end{abstract}

Keywords: Sartre, Existentialism, Freedom, Reality, Social philosophy, Consciousness

\footnotetext{
${ }^{1}$ Department of philosophy, McGill University. Address all correspondence to kexin.hu@mail.mcgill.ca.
} 
Sartre illustrates the structure of human consciousness by stating that "we have to deal with human reality as a being which is what it is not and which is not what it is" (Sartre, Being and Nothingness, 150). Consciousness is "what it is not," suggesting the nihilating structure of consciousness of which consciousness is always other than itself. Nihilation is, to some extent, a negating activity; however, to nihilate is not to completely cut one's consciousness from its relation to the world. Instead, consciousness relates to something that is always non-identical to itself. Only through nihilating things in the world and not identifying with them can consciousness take them up and give them meaning. The nihilating activity of consciousness is a meaning-making mechanism that proceeds in the mode of "for-itself." Since we are always conscious of something that is not consciousness itself, we must relate to other things in the world like our past and give them meaning. However, since consciousness is always nihilating, it is always non-identical to the past. Rather, consciousness must take up the past and give meaning to the past for itself. Sartre rejects the mode of "in-itself" as opposed to the mode of "for-itself" by stating that human consciousness is "not what it is" (Sartre, BN, 150). To be in the mode of "initself" is to identify consciousness with something, is to say that consciousness is identical to a thing, indicating a fixed identity. For example, the table is in the mode of "in-itself" because a table is an inanimate object which is a table, and a table is "what it is." However, consciousness cannot be reduced to a thing. If we believe that our past ultimately determines our identity, we are in the mode of "in-itself" as we identify entirely with the past. Consciousness cannot be in the mode of "in-itself" because consciousness is always non-identical to something; it is a non-identity rather than a fixed identity.

The nihilating structure of consciousness entails that consciousness is never identical to something. It also entails the radical freedom and responsibilities for consciousness to take up things in the world and give them meaning. Bad faith is a lived attempt by consciousness to flee from its nihilating structure; it is an attempt to reject the mode of "for-itself" and enter the mode of "in-itself." In other words, bad faith 
constantly tries to make consciousness a thing in order to negate the radical freedom and responsibilities of meaningmaking. However, bad faith is always a failed attempt because it cannot change the nihilating structure of consciousness; and the very structure of consciousness will always undermine the project of bad faith. I agree with Sartre's notion that bad faith is always a failed attempt because it is a form of self-deception and contradiction. Bad faith aims to conceal the radical freedom and responsibilities of consciousness from consciousness itself. In this case, consciousness is both "the deceiver and the deceived" (Sartre, BN, 139). However, the unity of consciousness does not allow it to be a deceiver and a deceived at the same time, as "[a deceiver] must know what the truth is exactly in order to conceal it more carefully" (Sartre, $B N, 140)$. Similarly, consciousness must realize its radical freedom before it starts the project of denying it. Consciousness cannot be the deceiver and the deceived at the same time because it cannot lie to itself about something that it does not even know. Since the condition for bad faith's success is built on the impossible duality of "the deceiver and the deceived" within a single consciousness, the structure of consciousness will always undermine bad faith.

According to Sartre, the nihilating structure of consciousness necessarily entails freedom. In other words, "to exist as consciousness is to be free" (Al-Saji, Sartrean Freedom and Bad Faith, 352) because it is always free in how it takes up things in the world and give them meaning. However, the radical freedom of consciousness seems to be in tension with the social roles that a social structure assigns to individuals. In a social structure where individuals are reduced to their social roles, they must take up such roles in the mode of "in-itself," as they are expected to behave according to their roles. In this case, social roles compromise the radical freedom of consciousness by leaving no room for consciousness to utilize its nihilating and meaning-making structure. In other words, in circumstances where individuals are asked to behave according to fixed social roles, it leaves very little leeway for consciousness to make meaning transcendent of such fixed roles. Sartre illustrates the pressure of social roles when he states that "a grocer who 
dreams is offensive to the buyer, because such a grocer is not wholly a grocer. Etiquette requires that he limit himself to his function as a grocer" (Sartre, BN, 152). The example of the grocer indicates how individuals are reduced to social roles, and how the meaning bestowed on such roles is up to "etiquette" instead of their consciousness. Alternatively, utilizing the nihilating activity of consciousness and believing they are other than or more than their social roles violates social roles and expectations. Due to the fear of consequences when violating the social structure, one may accept their social roles and assert they are indeed such roles in the mode of in-itself. In this case, the impossible duality of the deceiver and the deceived seems to be solved. The social structure and positionality take up the role of the deceiver. They overwhelm individuals' consciousness with social roles and obligations to the extent that individuals become unable to utilize their radical freedom and be other than their social roles.

The waiter in the coffee shop is another example that illustrates the threat social roles impose on the radical freedom of consciousness. The waiter in the coffee shop is too devoted to the role of being a waiter, "their movement is a little too precise; they bend forward a little too eagerly" (Sartre, BN, 151). The waiter is in bad faith because they are acting as if they are nothing more than a waiter; they are a waiter in the mode of in-itself and a waiter is what they are. However, if we take the social circumstances into account, perhaps the waiter cannot act in any other way because doing so puts them at the risk of losing their job and failing to meet other social responsibilities. In this case, the radical freedom of the waiter's consciousness is compromised, but not because their consciousness is concealing the radical freedom from itself in order to escape the responsibilities of meaningmaking. Instead, the rigid social roles hold the radical freedom hostage and prevent the waiter from even considering acting in any way differently from their current role as a waiter.

Social roles and positionality present a challenge to Sartre's account of radical freedom because the waiter may not have the freedom to choose whatever occupation they desire or simply leave the waitressing job. However, Sartre's notion of radical freedom emphasizes more on 
meaning-making than action. Acting differently than a waiter, leaving the waitressing job and getting a new job are possible ways for the waiter to utilize their radical freedom and not be in bad faith. However, these options all rely on an action-based type of freedom instead of a meaning-making type of freedom. Sartre's radical freedom does not imply that individuals can act randomly or choose freely between different options. Instead, Sartre focuses on the meaningmaking mechanism of our consciousness. The external social positionality puts pressure on consciousness's meaningmaking activity, but it does not change the nihilating structure of consciousness. Thus, consciousness is still the dominant meaning-making agent responsible for taking up social situations and giving them meanings. In Sartre's account, consciousness can recognize that social roles are threats to radical freedom, and how other people act within the social structure can reinforce such threats. However, consciousness is still free to decide how important the social roles are and how much weight is to put onto social roles. A social role that means a lot to other people does not necessarily have the same weight for me because the meaning of this role and its importance all depends on the meaning that my consciousness makes for itself. Individuals can still act according to their social roles without falling into bad faith because their actions do not indicate that they solely see themselves as a thing that is their social role. Rather, individuals utilize their radical freedom when they recognize that they are their social roles in the mode of "for-itself" where they identify themselves other than their social roles. They can still conform to social expectations but realize that they are more than their current roles and that their social identity is never fixed. Thus, the nihilating structure of consciousness remains intact even within an oppressive and rigid social structure. Even though individuals have different social roles and expectations, they nevertheless have the same structures of consciousness, making the meaning-making activity a type of freedom that everyone possesses.

Sartre argues that human consciousness is a nihilating activity that constantly identifies itself other than a thing; the very structure of consciousness comes with the radical freedom of taking 
up things in the world and giving them meaning. According to Sartre, any attempt to reject the very nihilating structure of consciousness and deny that consciousness is radically free in meaning-making is bad faith. The goal of bad faith is to make consciousness a being "in-itself" to pretend that it does not have the freedom or responsibilities of meaning-making because it simply exists as what it is. However, the project of bad faith is a contradiction because it relies on an impossible condition that simultaneously asks a consciousness to both live the freedom and hide this very freedom from itself. Social roles and social positionality put pressure on Sartre's notion of radical freedom. By assigning rigid social roles to individuals, social roles leave little room for consciousness to make meaning different from their given roles. In such a societal structure, the radical freedom of consciousness is compromised because individuals may not have the freedom to ignore their social roles. However, Sartre's notion of radical freedom emphasizes meaning-making more than actions. Social roles might limit people's options of taking different actions, but they do not undermine the inner structure of consciousness. Thus, the radical freedom of consciousness remains in a societal structure because how much meaning and weight one puts on a specific role is still varies depending on how much meaning one's consciousness makes out of it. 


\section{References}

Al-Saji, Alia. "Sartrean Freedom and Bad Faith: Social Identities and Situations." Introducing Philosophy for Canadians, by Robert C. Solomon and Douglas McDermid, Oxford University Press, Don Mills, Ont., 2011, pp. 352-356.

Sartre, Jean-Paul. Selections from The Philosophy of Jean-Paul Sartre. Edited by Robert D Cumming, New York: Random House, 1965. 